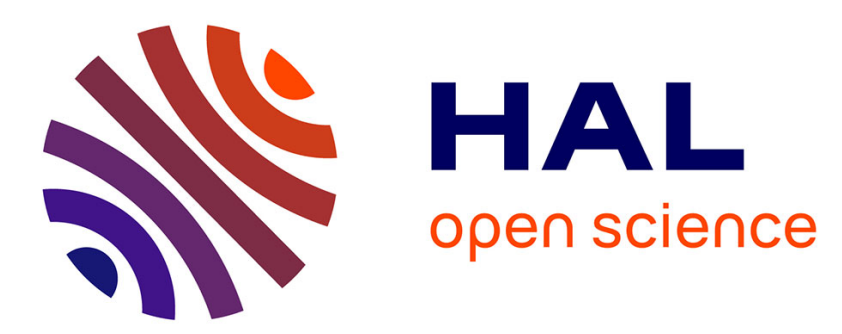

\title{
Limited impact of on native algal assemblages from rocky intertidal shores
}

\author{
Celia Olabarria, Iván F. Rodil, Mónica Incera, Jesús S. Troncoso
}

\section{To cite this version:}

Celia Olabarria, Iván F. Rodil, Mónica Incera, Jesús S. Troncoso. Limited impact of on native algal assemblages from rocky intertidal shores. Marine Environmental Research, 2009, 67 (3), pp.153. 10.1016/j.marenvres.2008.12.007 . hal-00501991

\section{HAL Id: hal-00501991 \\ https://hal.science/hal-00501991}

Submitted on 13 Jul 2010

HAL is a multi-disciplinary open access archive for the deposit and dissemination of scientific research documents, whether they are published or not. The documents may come from teaching and research institutions in France or abroad, or from public or private research centers.
L'archive ouverte pluridisciplinaire HAL, est destinée au dépôt et à la diffusion de documents scientifiques de niveau recherche, publiés ou non, émanant des établissements d'enseignement et de recherche français ou étrangers, des laboratoires publics ou privés. 


\section{Accepted Manuscript}

Limited impact of Sargassum muticum on native algal assemblages from rocky intertidal shores

Celia Olabarria, Iván F. Rodil, Mónica Incera, Jesús S. Troncoso

PII:

$$
\text { S0141-1136(08)00262-6 }
$$

DOI:

10.1016/j.marenvres.2008.12.007

Reference:

MERE 3311

To appear in:

Marine Environmental Research

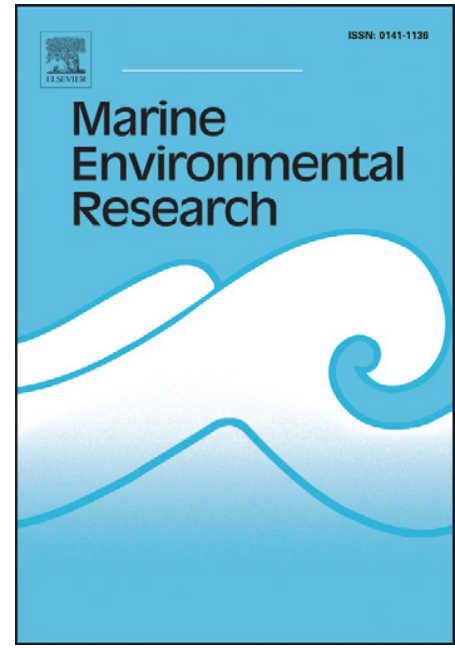

Received Date: 3 October 2008

Revised Date: $\quad 18$ December 2008

Accepted Date: $\quad 22$ December 2008

Please cite this article as: Olabarria, C., Rodil, I.F., Incera, M., Troncoso, J.S., Limited impact of Sargassum muticum on native algal assemblages from rocky intertidal shores, Marine Environmental Research (2008), doi: 10.1016/j.marenvres.2008.12.007

This is a PDF file of an unedited manuscript that has been accepted for publication. As a service to our customers we are providing this early version of the manuscript. The manuscript will undergo copyediting, typesetting, and review of the resulting proof before it is published in its final form. Please note that during the production process errors may be discovered which could affect the content, and all legal disclaimers that apply to the journal pertain. 


\section{Limited impact of Sargassum muticum on native algal assemblages from rocky intertidal shores}

\footnotetext{
Celia Olabarria $^{1 *}$, Iván F. Rodil ${ }^{1}$, Mónica Incera ${ }^{2}$, Jesús S. Troncoso ${ }^{1}$

${ }^{1}$ Departamento de Ecología e Biología Animal, Facultade de Ciencias del Mar, Universidade de Vigo, 36200Vigo, Spain.

${ }^{2}$ Centro Tecnológico del Mar-Fundación CETMAR, C/Eduardo Cabello s/n, 36208

Vigo, Spain

*Corresponding author: colabarria@uvigo.es
} 


\section{ABSTRACT \\ Invasive species represent a serious threat to natural ecosystems through a \\ 3 range of negative effects on native species in the region invaded. The invasive species \\ 4 Sargassum muticum has invaded several temperate regions worldwide including the \\ 5 Galician rocky shoreline (northwestern Spain) in western Europe. The main aim of \\ 6 this study was to assess if colonization by S. muticum has any effect on native algal \\ 7 assemblages by experimental removal of S. muticum. We predicted that in those plots \\ 8 where S. muticum plants were removed, the structure of native algal assemblages \\ 9 would differ from that in plots where S. muticum plants were untouched. In addition, \\ 10 we predicted that the effect of Sargassum removal would be more important than \\ 11 other causes of variability at the small scale investigated. Results indicated limited \\ 12 impact of S. muticum on native assemblages. The impact was only evident on the total \\ 13 number of native taxa and two understory morpho-functional groups, filamentous and \\ 14 foliose algae, rather than on the entire macroalgal assemblages.}

15

16 Key words: removal experiment, algal assemblages, biological invasions, rocky

17 intertidal, Sargasum muticum effects 


\section{Introduction}

The number of species anthropogenically introduced outside their natural ranges is rapidly increasing (Levin et al., 2002). Although only a very small proportion of transported and introduced species becomes invasive, the ability of these species to restructure and, therefore, change the functioning of a recipient habitat is great (Crooks, 2002). After loss of habitat, invasive species are the second leading cause of biodiversity loss, particularly in freshwater ecosystems (Vitousek et al., 1997; Mack et al., 2000; Ross et al., 2004). Besides imposing huge economic costs, invasive species may cause extinction of native species, reduction of genetic diversity, and biotic homogenization through a variety of mechanisms (Rahel, 2000). Biological invasions are increasing, especially in marine environments where they are linked to the intensification of international shipping, aquaculture and aquarium activity (Verlaque, 1994; Ribera and Bouderesque, 1995). In particular, marine macroalgae are a significant component of marine invasive species with 277 introduced species recorded in a recent review (see Williams and Smith, 2007). Displacement of existing flora by introduced algal species has been largely reported (Chambers et al., 1993; Piazzi et al., 2001). Replacement of dominant macroalgae by introduced species may provoke changes of the species composition and their trophic food webs (Piazzi et al., 2001). Several studies have focused on the effects of exotic algae and impacts on native assemblages (e.g. Viejo, 1997; Stæhr et al., 2000; Piazzi et al., 2001; Levin et al., 2002; Britton-Simmons, 2004; Sánchez and Fernández, 2005; Strong et al., 2006). Results indicate that impacts of exotic species may vary greatly depending on the invaded assemblages (e.g. Chapman, 1999). For example, the Japanese seaweed Codium fragile (Sur.) Harriot ssp. tomentosoides (van

Goor) Silva has detrimental effects on subtidal kelp communities in the northeast Atlantic 
native assemblages (Buschbaum et al., 2006). The green alga Caulerpa racemosa

(Forsskål) J. Agardh has strong effects on composition and structure of native assemblages at different habitats such as rocky bottoms and dead matter of the marine phanerogam Posidonia oceanica (Piazzi et al., 2001). Sargassum muticum (Yendo)

Fensholt is native to SE Asia, but its present distribution as an invasive species is widespread, including Europe, the Mediterranean Sea and the west coast of North America. This species becomes established in low intertidal and shallow subtidal habitats where it forms dense stands that may reduce light, dampen flow, increase sedimentation and reduce ambient nutrient concentrations available for native species (Britton-Simmons, 2004). In subtidal habitats S. muticum has been shown to have negative effects on native algae (Sánchez and Fernández, 2005), whereas in intertidal areas some studies suggest that it competes with native algae (e.g. DeWreede, 1983; Viejo, 1997) while other studies show no effects. These contradicting results suggest strong site-specific effects of S. muticum, making generalizations about the impact of this species difficult.

S. muticum was first observed on the Galician coast in 1986 (see Pérez-Cirera et al., 1989) and has since quickly colonized most of the Galician rias (sensu Vilas et al., 2005) increasing its abundance rapidly. Despite its rapid spread, no studies assessing consequences of the introduction of this species on native assemblages have been done in this area so far.

The objective of this study was to assess the effect of $S$. muticum on native algal assemblages using a removal experiment in which the presence of this species was manipulated. We predicted that if $S$. muticum is removed the remaining assemblages would be distinct, in terms of composition and structure, from those found in plots where S. muticum was present. In addition, we predicted that the effect 
78 of removal would be more important than other causes of variability at the small

79 spatial scale investigated (sites located $400 \mathrm{~m}$ apart).

80

81

\section{Material and Methods}

\subsection{Study area}

The study was carried out at Monte Lourido (42 $7^{\circ}$ 26' ' N; $8^{\circ} 49^{\prime} 34^{\prime \prime} \mathrm{W}$ ) in the Galician coast (NW Spain). Two sites 400 m apart were chosen. Site 1 was on a gently sloping rocky platform $\left(\sim 2^{\circ}\right.$ in slope $)$ running perpendicular to the sea and slightly more exposed than site 2 . The upper intertidal was dominated by Fucus spiralis and the mid and low intertidal was dominated by red, green or some conspicuous brown macroalgae (i.e. Sacchoriza polyschides) depending on the season. Site 2 was a long nearly horizontal platform interrupted at its seaward margin by a series of surge channels that run oblique to the shoreline and are sheltered from the direct wave action. The bottom of these channels was made of cobbles covered with sand. The upper intertidal contained less $F$. spiralis than Site 1 and mid and low intertidal assemblages were poorer in terms of number of species than Site 1. S. muticum was very abundant at both sites, although plants from Site 2 were bit longer and reached larger sizes than those at Site 1 (personal observation).

\subsection{Experimental design}

The experiment was performed in the low intertidal (0.4-0.8 $\mathrm{m}$ above the lowest astronomical tide) from April 2006 to March 2008. Ten permanent 50 x $50 \mathrm{~cm}$ plots were randomly establish along $80 \mathrm{~m}$ at each site. The corners of the plots were permanently marked using epoxy putty (IVEGOR) for identification. At each site, the experimental plots were arranged in a line parallel to shore separated by $\sim 5 \mathrm{~m}$ and randomly assigned to control (i.e. with Sargassum) or removal (i.e. without 
102 Sargassum) treatments with five replicates for each. In plots assigned to the removal

103 treatment, all S. muticum was manually eradicated, both from within the plots and

104 from a $50 \mathrm{~cm}$ buffer surrounding the plots. Each plant was removed by carefully

105 prying its holdfast off the rock substrate with a scrapper. The buffer zone was created

106 in order to reduce shading or other effects of adjacent S. muticum. Attention was paid

107 to not damage the understory assemblage or to alter the physical characteristics of the

108 substratum. The removal plots were kept free of $S$. muticum throughout the course of

109 experiment by removing any new $S$. muticum recruits from plots and adjacent buffer

110 zones once a month. The control plots were not altered. The experiment was sampled

111 once prior to the beginning of the experiment and then every month, although time

112 and weather constraints prevented sampling on some dates (site 1 in October 2006 and

113 site 2 in November 2006, January and August 2007).

114 Percentage cover of macroalgae was estimated using a 50 x $50 \mathrm{~cm}$ metallic

115 quadrat divided into 25 sub-quadrats of $10 \times 10 \mathrm{~cm}$, and a score from 0 to $4 \%$ was

116 given to each taxon in each sub-quadrat after visual inspection. Final cover was

117 obtained by summing over the 25 scores obtained in the sub-quadrats (Dethier et al.,

118 1993). Species were identified in the field but when doubt existed, samples were

119 collected for further identification in the laboratory. Macroalgae were grouped into

120 morpho-functional groups based on similarities in morphology and resource use

121 (foliose, filamentous, corticated, leathery, articulated calcareus and encrusting algae;

122 sensu Steneck and Dethier, 1994). In addition, number of native species and diversity

$123\left(\mathrm{H}^{\prime}\right)$ were estimated for each plot.

\section{2.3. Statistical analysis}

125 Since experimental plots were repeatedly sampled over time (i.e. 20 sampling

126 dates), a technique that could account for temporal autocorrelation was necessary. 
127 Data (percentage cover of main morpho-functional groups, number of native taxa and

128 diversity) were analysed using Population-Averaged Generalized Estimating

129 Equations (PA-GEEs), an extension of GLMs for correlated data (Liang and Zeger,

130 1986). PA-GEEs were run using the "geeglm" procedure in the R program, version

131 R2.2.1 (R Development Core Team 2005), specifying a link function and an error

132 structure for the residuals. We specified a first order autoregressive model AR (1) in

133 all the analyses assuming time dependence for each plot. For data expressed as

134 percentage cover and diversity, a Gaussian distribution of the error terms was

135 assumed and we used an identity link function. For data expressed as number of algal

136 species, a Poisson distribution of the error terms was assumed, and we used a log-link

137 function.

138 Two-way crossed analysis of similarity (ANOSIM) (Clarke, 1993) on fourth

139 root transformed data of percentage cover for each species was used to test for

140 differences in assemblages between treatments and over time at each site separately.

141 Treatment with two levels (control and removal) and time with 10 levels (April, July,

142 September, December 2006 and 2007, and February 2007 and 2008) were the factors

143 in the analysis. Pair-wise comparisons were also calculated. In addition, responses of

144 assemblages to treatments were visualised by non-metric multidimensional scaling

145 (nMDS) on the basis of Bray-Curtis similarity matrices on fourth-root transformed

146 percentage cover data. For all analyses, S. muticum was omitted from the data set to

147 check if the possible differences between treatments were caused not by the presence

148 of this species, but by changes in the remaining assemblages. Species that mostly

149 contributed to the dissimilarity/similarity between the two experimental treatments

150 were identified using SIMPER analysis (Clarke, 1993). All the calculations were

151 performed using PRIMER 6 for Windows (Plymouth, UK). 
152

153

154

155

156

157

158

159

160

161

162

163

164

165

166

167

168

169

170

171

172

173

174

175

\section{Results}

The percentage cover of $S$. muticum varied significantly between treatments (PA-GEEs; treatment: estimate: -15.36 , standard error: $2.58, p<0.001)$. Thus in control plots the mean percentage cover of $S$. muticum was $29.3 \pm 2.7$ and $42.7 \pm 3 \%$ at site 1 and site 2, respectively, whereas in removal treatments the mean percentage cover of the alga was $5 \pm 1.3$ and $7.2 \pm 1.7 \%$ at site 1 and site 2 , respectively (Fig. 1).

\subsection{Effects of S. muticum on morpho-functional groups}

Removal of S. muticum resulted in a significant increase of the mean percentage cover of filamentous and foliose algae ( $p<0.05$; Table 1, Fig. 2 a,b). Mean percentage cover of encrusting algae also increased in those plots where S. muticum was removed, but this increase was marginally non-significant ( $p=0.056$; Table 1 , Fig. 2c). The removal also affected the mean number of taxa (used as a surrogate measure of native species diversity), with significant lower values occurring in control plots, especially at site $2(p<0.05$; Table 1 , Fig. 2 d). The effect of $S$. muticum on these morpho-functional groups was also consistent across sites (i.e. non-significant interaction treatment $\mathrm{x}$ site, $p>0.05$; Table 1). Diversity and percentage cover of corticated, leathery and calcareous algae were not affected significantly by treatments (neither as main effect nor in interaction with site).

\subsection{Changes in assemblages}

Removal of S. muticum did not affect the composition of macroalgal assemblages. Two-way crossed ANOSIM results showed signifant differences between sites over time (Table 2, Fig. 3), but not between treatments (differences between treatments: site $1, \mathrm{R}=0.04, p>0.05$; site $2, \mathrm{R}=0.08, p>0.05$ averaged across all sampling times). There were only significant differences between treatments in 
176

177

178

179

180

181

182

183

184

185

186

187

188

189

190

191

192

193

194

195

196

197

198

199

200

April and September 2007 (Table 2). Time (monthly and interannually) differences in macroalgae assemblage structure (Fig. 3) were also detected by ANOSIM at both sites (differences among time factor: site $1, \mathrm{R}=0.519, p<0.01$; site $2, \mathrm{R}=0.465, p<0.01$;

Table 2; Figure 3). Pair-wise comparisons detected differences in macroalgal assemblages in most cases (Table 2).

The foliose alga Ulva rigida (7.07\%), the encrusting alga Lithophyllum incrustans (6.62\%), the leathery alga Bifurcaria bifurcata $(6.17 \%)$ and the articulated calcareus alga Corallina officinalis $(4.84 \%)$ were the species that mostly contributed to the dissimilarity between assemblages in both control and removal plots over time. In March 2008, 2 years after the start of the experiment, B. bifurcata (8.62\%), $U$. rigida (7.6\%), L. incrustans (7.28\%) and C. officinalis (6.06\%) still explained the highest contribution to the observed dissimilarity among assemblages.

S. muticum was very abundant in control plots during the whole experiment, although the percentage cover declined in late summer (illustrated by site 1 in Fig. 4 a). The following months after removal, Ulva rigida and Corallina officinalis dominated the primary substratum (illustrated by site 1 in Fig. 4 b, c; SIMPER). The decrease of the former during autumn and winter was followed by an increase in percentage cover of L. incrustans (illustrated by site 1 in Fig. 4 d). In contrast, $B$. bifurcata was not abundant in the removal plots (illustrated by site 1 in Fig. 4e). No significant differences between treatments were detected in percentage cover of these native species (PA-GEEs: $p>0.05$ ) except for $U$. rigida (PA-GEEs: $p<0.01$;

Estimate: 2.86, S.E: 1.06; Fig. 4 b).

\section{Discussion}

Results indicated limited impact of $S$. muticum on native assemblages. The impact was evident on the total number of native taxa and two understory morpho- 
201 functional groups, filamentous and foliose algae, rather than on the entire macroalgal

202 assemblages.. In particular, the total number of taxa as well as the percentage cover of

203 filamentous and foliose algae was smaller in control than removal plots. In addition,

204 these effects were consistent at small spatial scale as predicted.

205 Studies of $S$. muticum have varied widely in their conclusions about its effect

206 on native assemblages. In general, studies done on intertidal shores have found little

207 (Buschbaum et al., 2006; Harries et al., 2007) or no impact of S. muticum (e.g.

208 DeWreede, 1983; Viejo, 1997; Sánchez and Fernández, 2005), but studies in subtidal

209 habitats have indicated relatively strong effects (Ambrose and Nelson, 1982; Stæhr et

210 al., 2000; Brittom-Simmons, 2004). Nevertheless, the impact of S. muticum on native

211 assemblages not only depends on the type of habitat, but also on the abundance of $S$.

212 muticum (Viejo, 1997, Britton-Simmons, 2004; Stæhr et al., 2000). According to this,

213 effect of Sargassum should be more evident in densely colonized areas, where this

214 species should be more likely to provoke changes in native macroalgal assemblages

215 through competitive interactions (Ambrose and Nelson, 1982; Viejo, 1997; Britton-

216 Simmons, 2004). However, at low densities effects of invader on native macroalgal

217 assemblages might be very weak (see Viejo, 1997; Britton-Simmons, 2004). This

218 experiment was conducted at sites where the abundance of S. muticum was

219 comparatively low because the low intertidal corresponds to the upper end of its

220 distribution. Therefore, one may expect that the impact of S. muticum on native

221 assemblages is weaker because it is less abundant in this tidal zone.

222 Our results indicated a larger number of native taxa in those plots where

223 Sargassum was removed. Results from studies in marine benthic assemblages are

224 scarce and conflicting regarding relationships between diversity and potential for

225 invasion. For example, Dunstan and Johnson (2004) found positive relationships 
226

227

228

229

230

231

232

233

234

235

236

237

238

239

240

241

242

243

244

between species richness and abundance of invaders using assemblages of sessile invertebrates. Conversely, other experimental and observational studies have reported negative relationships between the numbers of invasive and native taxa (Stachowicz et al., 1999; 2002; White and Shurin, 2007). In fact, White and Shurin (2007) showed that $S$. muticum was less abundant in areas with high diversity of native species. In our study, the observed negative relationship may have different explanations. Firstly, Sargassum may outcompete native species and therefore reduce native diversity, or secondly, its environmental niche at low intertidal may coincide with areas of low native diversity. The latter explanation, however, seems very unlikely because the low intertidal area on the northwestern Iberian rocky shores is not a species-poor zone. In fact, low intertidal assemblages on this coast are highly diverse and show important spatial variation in species composition at scale of a few metres (see Araujo et al., 2005). Nevertheless, this experiment did not allow us to disentangle such possibilities. Previous studies on S. muticum have indicated the important role of functional groups in the invasion process (Viejo, 1997; Britton-Simmons, 2006). Recent findings of Arenas et al. (2006) have pointed out that identity of functional groups is more decisive than functional richness in determining the resistance of marine macroalgal assemblages (Arenas et al., 2006). Functional groups play an important role in the invasion process due largely to their effect on the primary resource requirements of space and light (Arenas et al., 2006; Britton-Simmons, 2004; 2006). Alternatively, different functional groups that present different survival strategies may be affected differently by invasive species (see Viejo, 1997). In this study we found a negative effect of $S$. muticum on the percentage cover of foliose and filamentous algae. These results partially agree with those reported by Viejo (1997) that found an impact of Sargassum on the leathery and foliose algae. Although several mechanisms 
251 underlying the invasion process have been proposed to explain changes in native 252 macroalgal assemblages (Ambrose and Nelson, 1982; Critchley et al., 1990; Vadas et 253 al., 1992; Viejo, 1997; Britton-Simmons 2004) we only can speculate on the causative 254 mechanisms. For example, foliose algae, mainly composed of the opportunistic 255 species Ulva sp, might be inhibited by Sargassum by pre-emption of space (see Viejo, 256 1997). Foliose and filamentous algae might be also negatively influenced by 257 Sargassum due to competition for light. In fact, Britton-Simmons (2004) has 258 demonstrated experimentally the negative effect of Sargassum canopy on growth of 259 understory species and Arenas et al. (2006) have found that filamentous species such 260 as Ceramiales are mainly affected by light.

261 In summary, results suggest that there was limited effect of Sargassum on 262 macroalgal assemblages. It might be possible that the spatial (i.e. 50 x $50 \mathrm{~cm}$ plots) 263 and temporal (i.e. 2 years) scales used in this study were not appropriate to detect a 264 stronger impact. In fact, previous studies focused on effects of Sargassum on 265 macroalgal assemblages have used larger temporal scales, i.e. $\geq 3$ years (e.g. Viejo, 266 1997; Britton-Simmons, 2004, Sánchez and Fernández, 2005). The fact that two 267 morpho-functional groups were affected by Sargassum also highlights the importance 268 of functional groups in the invasion process, and the need to do manipulative 269 experiments in which functional groups are altered (see Arenas et al., 2006; Britton270 Simmons, 2006).

\section{Acknowledgments}

This research has been supported by the Spanish Government through the

274 Ministry of Education and Science (PROJECT CGL2005-02269). Funds to I.F. Rodil

275 were provided in the course of a Maria Barbeito grant (Xunta de Galicia). 


\section{References}

277

278

279

280

281

282

283

284

285

286

287

288

289

290

291

292

293

294

295

296

297

298

299

300

301

302

303

304

305

306

Ambrose, R.F., Nelson, B.V., 1982. Inhibition of giant kelp recruitment by an introduced brown alga. Botanica Marina 25, 265-267.

Araujo, R., Bárbara, I., Sousa-Pinto, I., Quintino, V., 2005. Spatial variability of intertidal rocky shore assemblages in the northwest coast of Portugal. Estuarine, Coastal and Shelf Science 64, 658-670.

Arenas, F., Sánchez, I., Hawkins, S.J., Jenkins, S.R., 2006. The invasibility of marine algal assemblages: role of functional diversity and identity. Ecology 87 (11), 2851-2861

Britton-Simmons, K.H., 2004. Direct and indirect effects of the introduced alga Sargassum muticum on benthic, subtidal communities of Washington State, USA. Marine Ecology Progress Series 277, 61-78.

Britton-Simmons, K.H., 2006. Functional group diversity, resource preemption and the genesis of invasion resistance in a community of marine algae. Oikos 113, 395-401.

Buschbaum, C., Chapman, A.S., Saier, B., 2006. How an introduced seaweed can affect epibiota diversity in different coastal systems. Marine Biology 148, 743754.

Chambers, P.A., Barko, J.W., Smith, C.S., 1993. Evaluation of invasions and declines of submersed aquatic macrophytes. Journal of Aquatic Plant Management 31, 218-220.

Chapman, A.S., 1999. From introduced species to invader: what determines variation in the success of Codium fragile ssp. tomentosoides (Chlorophyta) in the North Atlantic Ocean?. Helgolander Meeresunters 52, 277-289.

Clarke, K.R., 1993. Nonparametric mutivariate analises of changes in community structure. Australian Journal of Ecology 18, 117-143.

Crooks, J.A., 2002. Characterizing ecosystem-level consequences of biological invasions: The role of ecosystem engineers. Oikos 97, 153-166.

Critchley, A.T., De Visscher, P.R.M., Nienhuis, P.H., 1990. Canopy characteristics of the brown alga Sargassum muticum (Fucales, Phaeophyta) in Lake Grevelingen, southwest Netherlands. Hydrobiologia 204/205, 211-217. 
Dethier, M.N., Graham, E.S., Cohen, S., Tear, L.M., 1993. Visual versus randompoint percent cover estimations: 'objective' is not always better. Marine Ecology Progress Series 110, 9-18.

DeWreede, R.E., 1983. Sargassum muticum (Fucales, Phaeophyta): regrowth and interaction with Rhodomela larix (Ceramiales, Rhodophyta). Phycologia 22, 153-160.

Dunstan, P.K., Johnson, C.R., 2004. Invasion rates increase with species richness in a marine epibenthic community by two mechanisms. Oecologia 138, 285-292.

Harries, D.B., Harrow, S., Wilson, J.R., Mair, J.M., Donnan, D.W., 2007. The establishment of the invasive alga Sargassum muticum on the west coast of Scotland: a preliminary assessment of community effects. Journal of Marine Biological Association of United Kingdom 87, 1057-1067.

Levin, P.S., Coyer, J.A., Petrik, R., Good, T.P., 2002. Community-wide effects of nonindigenous species on temperate rocky reefs. Ecology 83 (11), 3182-3193.

Liang, K.Y., Zeger, S.L., 1986. Longitudinal data analysis using generalized linear models. Biometrika 73 (19), 13-22.

Mack, R.N., Simberloff, D., Lonsdale, W.M., Evans, H., Clout, M., Bazzaz, F.A., 2000. Biotic invasions: causes, epidemiologoy, global consequences, and control. Ecological Applications 10, 689-710.

Pérez-Cirera, J.L., Cremades, J., Bárbara, I., 1989. Precisiones sistemáticas y sinecológicas sobre algunas algas nuevas para Galicia o para las costas atlánticas de la Península Ibérica. Anales del Jardín Botánico de Madrid 46, $35-45$.

Piazzi, L., Ceccherelli, G., Cinelli, F., 2001. Threat to macroalgal diversity: effects of the introduced green alga Caulerpa racemosa in the Mediterranean. Marine Ecology Progress Series 210, 140-159.

Rahel, F.J., 2000. Homogenization of fish faunas across the United States. Science 288, 854-856.

R Development Core Team, 2005. R: A language and environment for statistical computing, reference index version 2.1.1. R Foundation for Statistical Computing, Vienna, Austria. Available from: http://www.R-project.org

Ribera, M.A., Bouderesque, C.F., 1995. Introduced marine plants, with special referente to macroalgae: mechanisms and impact, in: Round, F.E., Chapman, D.J., Progress in Phycological Research, Biopress LTD Publ., pp. 187-268. 
Ross, D.J., Johnson, C.R., Hewitt, C.L., Ruiz G.M., 2004. Interaction and impacts of two introduced species on a soft-sediment marine assemblage in SE Tasmania. Marine Biology 144, 747-756.

Sánchez, I., Fernández, C., 2005. Impact of the invasive seaweed Sargassum muticum (Phaepohyta) on an intertidal macroalgal assemblage. Journal of Phycology 41, 923-930.

Stachowicz, J.J., Whitlatch, R.B., Osman, R.W., 1999. Species diversity and invasion resistance in a marine ecosystem. Science 286, 1577-1579.

Stachowicz, J.J., Fried, H., Osman, R.W., Whitlatch, R.B., 2002. Biodiversity, invasion resistance, and marine ecosystem function: reconciling pattern and process. Ecology 83, 2575-2590.

Steneck, R.S., Dethier, M.N., 1994. A functional group approach to the structure of algal-dominated communities. Oikos 69 (3), 476-497.

Strong, J.A., Dring, M.J., Maggs, C.A., 2006. Colonisation and modification of soft substratum habitats by the invasive macroalga Sargassum muticum. Marine Ecology Progress Series 321, 87-97.

Stæhr, P.A., Pedersen, M.F., Thomsen, M.S., Wernberg, T., Krause-Jensen, D., 2000. The invasion of Sargassum muticum in Limfjorden (Denmark) and its possible impact on the indigenous macroalgal community. Marine Ecology Progress Series 207, 79-88.

Vadas R.L. Sr., Johnson, S., Norton, T.A., 1992. Recruitment and mortality of early post-settlement stages of benthic algae. British Phycological Journal 27, 331351.

Verlaque, M., 1994. Checklist of introduced plants in the Mediterranean: origins and impact on the environment and human activities. Oceanologica Acta 17, 1-23.

Viejo, R.M., 1997. The effects of colonization by Sargassum muticum on tidepool macroalgal assemblages. Journal of Marine Biological Association of the United Kingdom 77, 325-340.

Vilas, F., Bernabeu A,. Méndez G., 2005. Sediment distribution pattern in the Rias Baixas (NW Spain): main facies and hydrodynamic dependence. Journal of Marine Systems. 54, 261-276.

Vitousek, P.M., Mooney, H.A., Lubchenco, J., Melillo, J.M., 1997. Human domination of Earth's Ecosystems. Science 277, 494-499. 
374 White, L.F., Shurin, J.B., 2007. Diversity effects on invasion vary with life history

375 stage in marine macroalgae. Oikos 116 (7), 1193-1203.

376 Williams, S.L., Smith, J.E., 2007. A global review of the distribution, taxonomy and

377 ecological impacts of introduced seaweeds. Annual Review of Ecology

378 Evolution and Systematics 38, 327-359.

379

380 
Table 1. Results of Population-Averaged Generalized Estimating Equations examining the effects of Sargassum muticum on native algal assemblages

\begin{tabular}{|c|c|c|c|c|c|c|c|c|c|c|c|c|c|c|c|c|}
\hline & \multicolumn{2}{|c|}{$\begin{array}{l}\text { Number of } \\
\text { native taxa }\end{array}$} & \multicolumn{2}{|c|}{ Diversity } & \multicolumn{2}{|c|}{$\begin{array}{c}\text { Filamentous } \\
\text { algae }\end{array}$} & \multicolumn{2}{|c|}{$\begin{array}{c}\text { Foliose } \\
\text { algae }\end{array}$} & \multicolumn{2}{|c|}{$\begin{array}{c}\text { Corticated } \\
\text { algae }\end{array}$} & \multicolumn{2}{|c|}{ Leathery algae } & \multicolumn{2}{|c|}{$\begin{array}{c}\text { Calcareous } \\
\text { algae }\end{array}$} & \multicolumn{2}{|c|}{$\begin{array}{c}\text { Encrusting } \\
\text { algae }\end{array}$} \\
\hline & $\mathrm{E}$ & SE & $\mathrm{E}$ & $\mathrm{SE}$ & $\mathrm{E}$ & $\mathrm{SE}$ & $\mathrm{E}$ & SE & $\mathrm{E}$ & SE & $\mathrm{E}$ & SE & $\mathrm{E}$ & $\mathrm{SE}$ & $\mathrm{E}$ & $\mathrm{SE}$ \\
\hline Intercept & $2.09^{* * *}$ & 0.04 & $1.16^{* * *}$ & 0.03 & $3.14 * * *$ & 0.38 & $17.15^{* * *}$ & 1.22 & 12.54 & 1.31 & $7.50 * * *$ & 1.45 & $7.81 * * *$ & 0.99 & $7.79^{* * *}$ & 1.54 \\
\hline Treatment $(\mathrm{T})$ & $0.07 *$ & 0.04 & -0.02 & 0.03 & $0.81 *$ & 0.38 & $3.06^{*}$ & 1.22 & 0.04 & 1.31 & -2.17 & 1.45 & 0.27 & 0.99 & $2.98 \dagger$ & 1.54 \\
\hline Site $(S)$ & -0.02 & 0.04 & 0.05 & 0.03 & -0.7 & 0.38 & $-3.49 * *$ & 1.22 & -2.47 & 1.31 & $-3.33^{*}$ & 1.45 & 0.83 & 0.99 & $3.03^{*}$ & 1.54 \\
\hline $\mathrm{T} \times \mathrm{S}$ & 0.05 & 0.04 & 0.00 & 0.03 & 0.04 & 0.38 & -0.10 & 1.22 & 2.34 & 1.31 & 1.87 & 1.45 & -1.37 & 0.99 & -0.45 & 1.54 \\
\hline Correlation parameter & 0.63 & 0.04 & 0.37 & 0.05 & 0.18 & 0.05 & 0.37 & 0.04 & 0.46 & 0.10 & 0.89 & 0.03 & 0.68 & 0.06 & 0.89 & 0.02 \\
\hline Scale parameter & 0.79 & 0.09 & 0.08 & 0.01 & 47.3 & 13.68 & 310 & 48.8 & 129.1 & 22.8 & 79.8 & 26.8 & 58.9 & 8.97 & 79 & 21 \\
\hline
\end{tabular}

$\mathrm{E}=$ estimate; $\mathrm{SE}=$ standard error. ${ }^{*} p<0.05 ; * * p<0.01 ; * * * p<0.001 ; \dagger$ marginally non-significant $(p=0.056)$ 
Table 2. Results of the ANOSIM and pair-wise tests for differences on macroalgal assemblages between treatments (control and removal) and sites (1 and 2) over time (dates as in Figure 3)

\begin{tabular}{ccccccc}
\hline Years & \multicolumn{2}{c}{2006} & \multicolumn{2}{c}{2007} & \multicolumn{2}{c}{2008} \\
Months & Site & Treatment & Site & Treatment & Site & Treatment \\
\hline April & $0.424^{* *}$ & -0.074 & $0.384^{* *}$ & $0.226^{*}$ & + & + \\
July & $0.414^{* *}$ & 0.074 & $0.48^{* *}$ & 0.144 & + & + \\
September & $0.521^{* *}$ & 0.044 & $0.232^{*}$ & $0.228^{*}$ & + & + \\
December & $0.356^{* *}$ & 0.02 & $0.48^{* *}$ & 0.134 & + & + \\
February & + & + & $0.476^{* *}$ & -0.074 & $0.214^{*}$ & -0.022 \\
\hline
\end{tabular}

time (10 levels) and treatment (2 levels) as factors in the analysis. ${ }^{*} p<0.05 ;{ }^{*} p<0.01 ;+$ not sampled 


\section{Figure captions}

Fig. 1. Percentage cover (mean $\pm \mathrm{SE} ; n=100$ ) of Sargassum muticum in control and removal plots over the course of the experiment.

Fig. 2. Percentage cover (mean \pm SE; $n=5$ ) of filamentous (a), foliose (b), encrusting algae(c), and number of native taxa (d) at site 1 and site 2 .

Fig. 3. Non-metric multidimensional scaling (nMDS) for differences in assemblages showing temporal changes between treatments at site 1 and site $2(n=5)$. The first data (April 2006) for each site belongs to the pre-removal samples. Circle: site 1, triangle: site 2.

Fig. 4. Percentage cover (mean $\pm \mathrm{SE} ; n=5$ ) of Sargassum muticum (a), Ulva rigida (b), Corallina officinalis (c), Lithophyllum incrustans(d), and Bifurcaria bifurcata (e), over time at site 1 . The first data point (April 2006) represents the pre-removal samples. S. muticum was excluded from the ANOSIM and SIMPER analyses. 


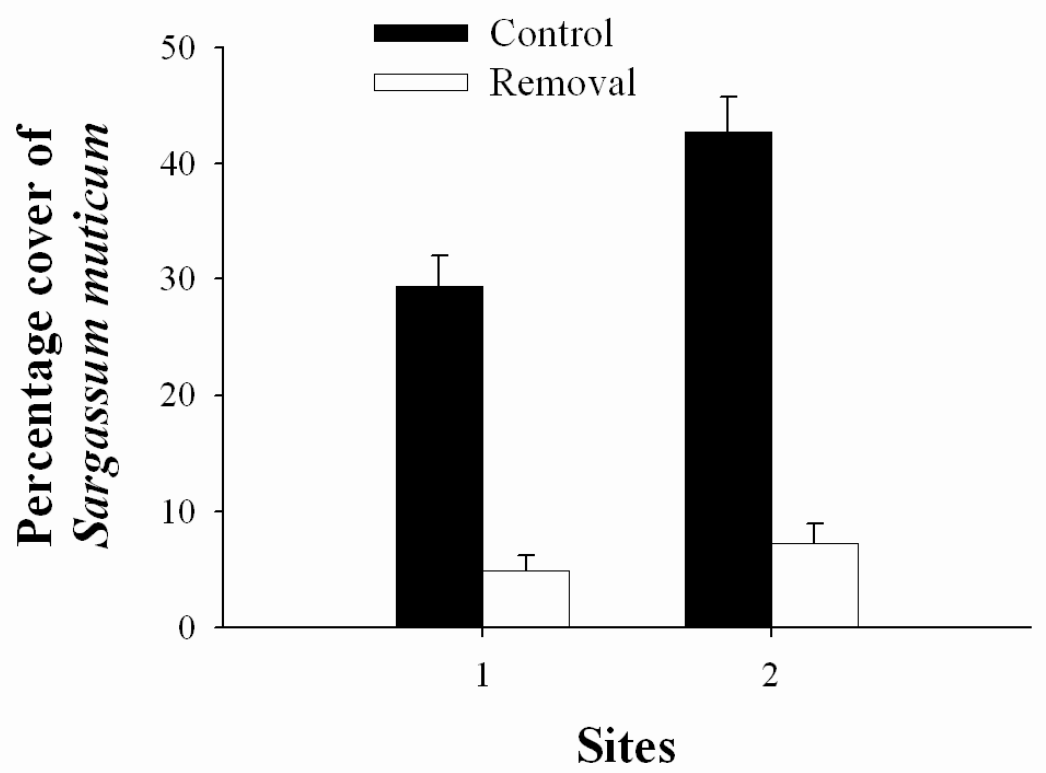

Fig. 1 Olabarria et al. 


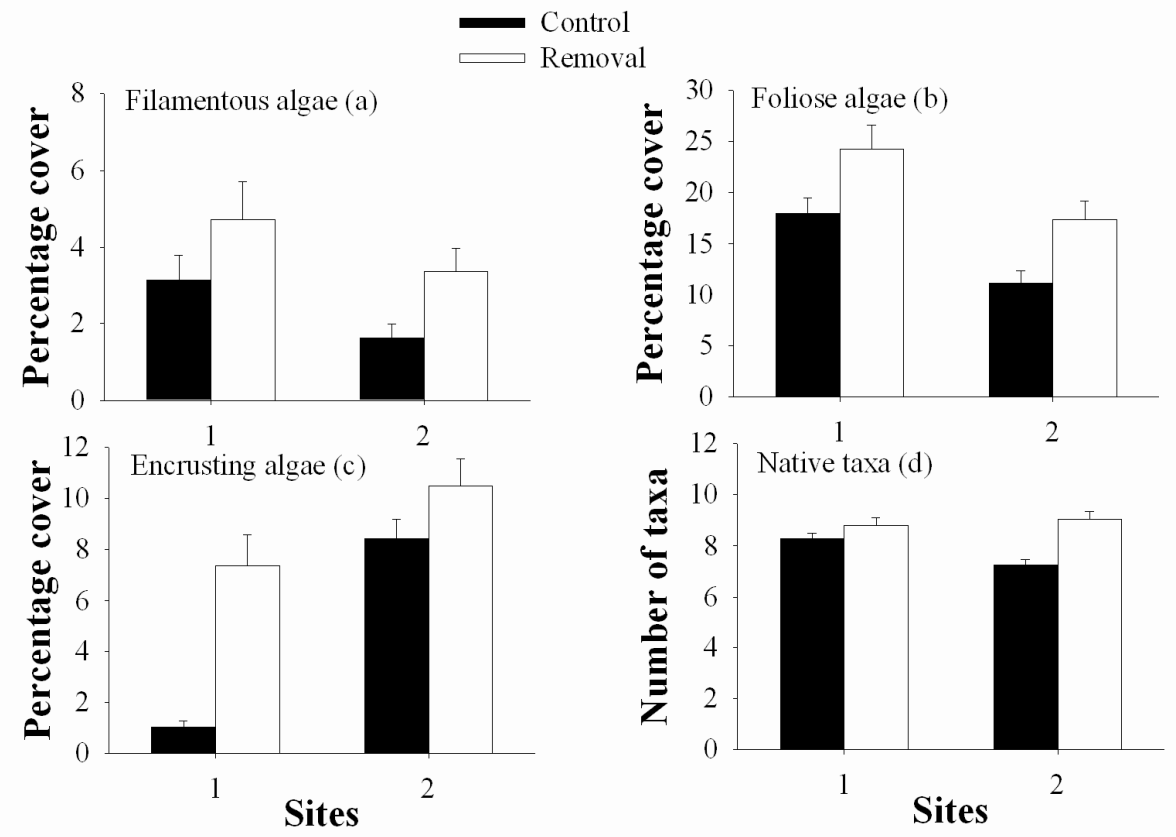

Fig. 2 Olabarria et al. 


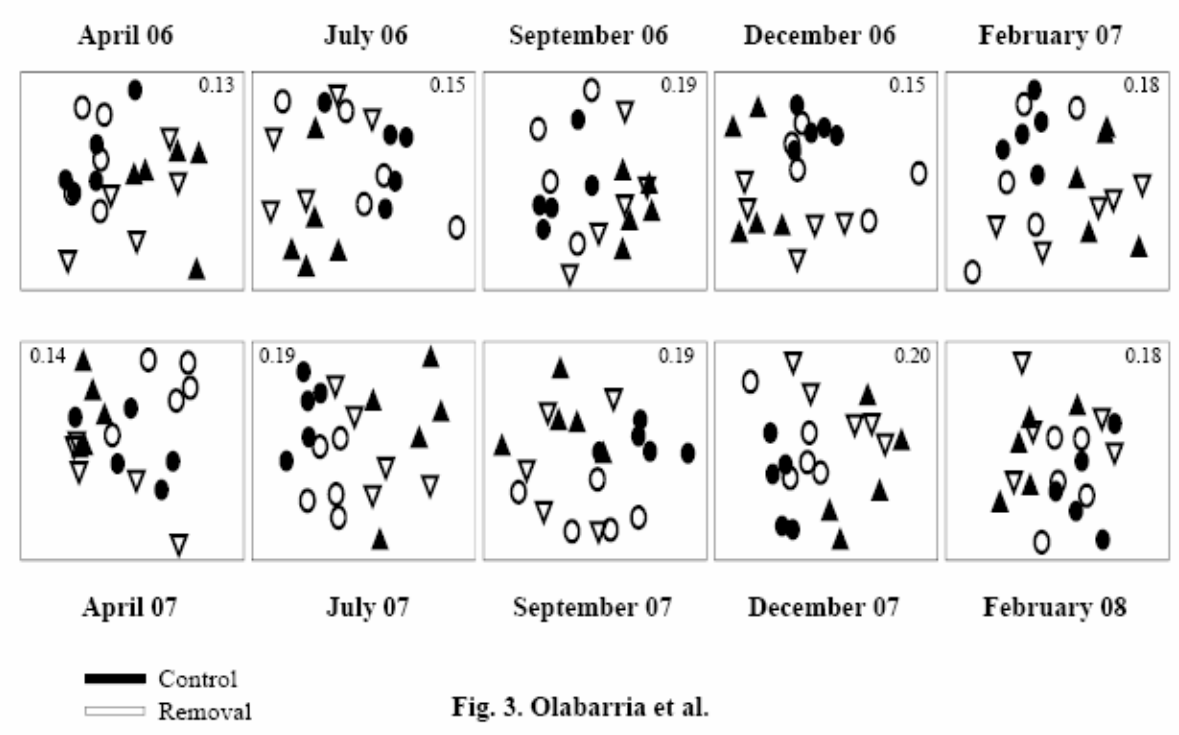




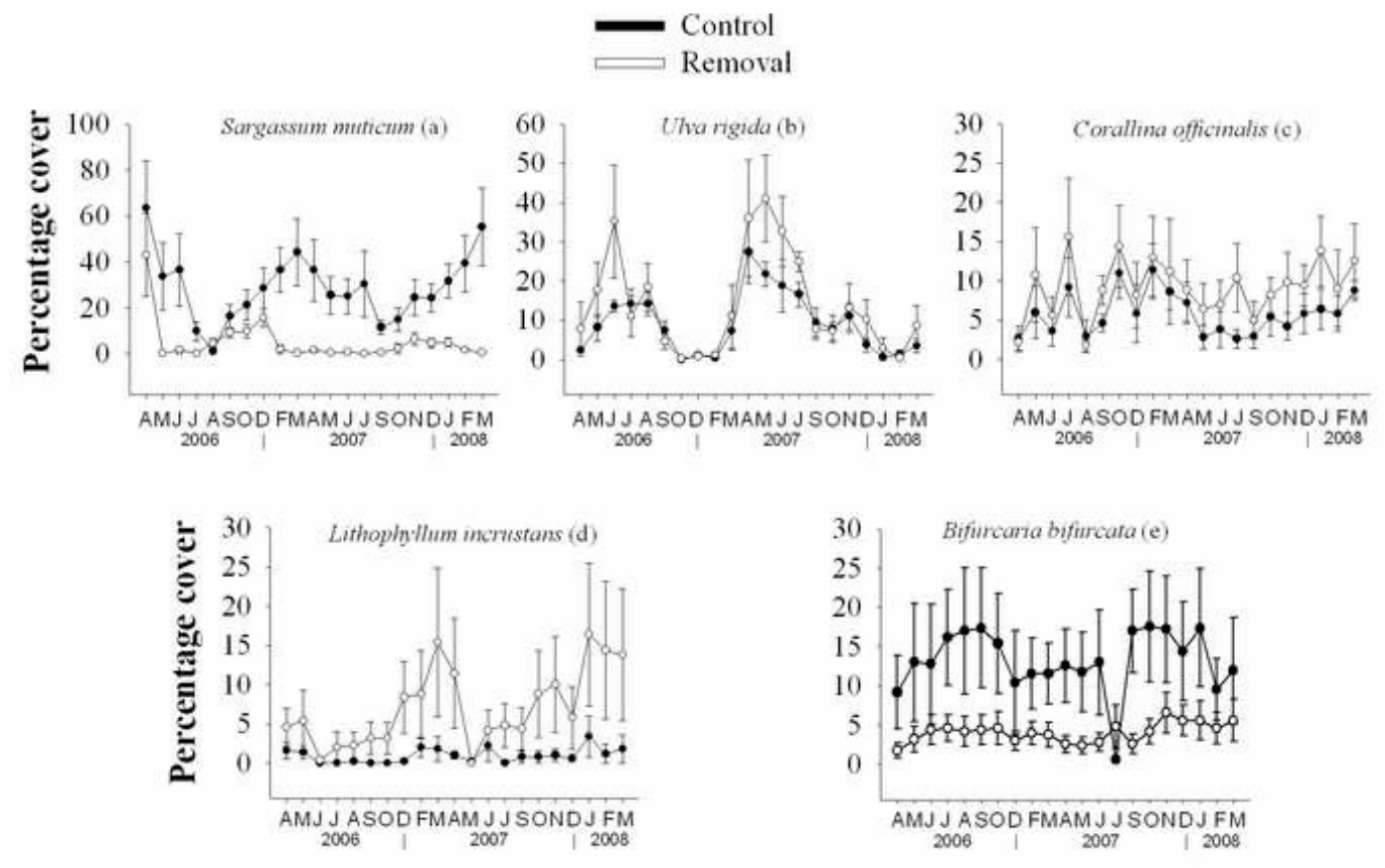

Fig. 4 Olabarria et al. 